\title{
Impact of M\&A Announcement on Stock Returns of Acquirer Companies: New Evidence from Indian Stock
} Market

\author{
Richa Vij \\ Associate Professor \\ Maharaja Agrasen Institute of Management Studies \\ Rohini, Delhi-110085, India
}

Received: May 18, 2017

Accepted: June 6, 2017

Published: June 25, 2017

doi:10.5296/wjbm.v3i1.11248

URL: http://dx.doi.org/10.5296/wjbm.v3i1.11248

\begin{abstract}
:
Mergers and Acquisitions (M\&As) are often used as preferred tools of corporate structuring to serve a variety of business objectives and add value for the shareholders. Earlier studies have triggered a number of questions regarding the impact of M\&As for the shareholders of acquiring companies. This paper focuses on the M\&A among Indian companies and the response of the Indian capital market to such attempts as reflected in the changes in the stock return for different window periods close the M\&A announcement. The findings of the present study suggest that there is significant impact of M\&A announcement on stock returns for almost half of the sample acquirer companies. The study offers evidence in support of the contention that Indian stock market is not efficient in the semi-strong form with respect to M\&A announcement information for acquirer companies and emphasizes that investment analyst cannot ignore the information regarding the M\&A deals.
\end{abstract}

Keywords: Merger and Acquisition (M\&A), Corporate restructuring, Market efficiency, Event study analysis 


\section{Introduction}

Mergers and Acquisitions (M\&As) are often used as preferred tools of corporate structuring to serve a variety of business objectives. With the impressive increase in the number of M\&As, there has been increased interest in the issues regarding the impact of such restructuring activities on effectiveness of businesses. A merger is popularly understood to be a fusion of two companies. It refers to the merging of one company into another or two companies getting merged to form a new company. Acquisition or takeover, on other hand, denotes a company acquiring controlling stake in another so that the acquirer can have management control over the firm. Mergers are different from acquisitions. An acquisition implies that a company unilaterally relinquishes its independence and adapts to another firm's plans while in mergers all combining firms relinquish their independence and co-operate resulting in common corporation. In other words, corporate takeover is a corporate action where an acquiring company makes a bid for a target company. Mergers and acquisitions (M\&As) as a means for inorganic growth, are increasingly being used, the world over for undertaking restructuring of leading business enterprises. It is observed as a strategy for achieving larger size and faster growth in market share and reach, and to become more competitive through economies of scale. Indian companies are also aggressively building capacities via M\&As to cater to the growing domestic and global markets.

\subsection{Prior Studies, Objectives and Methodology}

A number of studies offer evidence in support of the contention that some M\&As out-perform others (see e.g. Martynova et al., 2006; Seth, Song, \& Pettit, 2002). It is also observed that M\&A activities have a tendency to cluster as they may be triggered by the changes in the business environment caused by economic, political or social developments (Sudarsanam, 2003). Changes in business environment may cause change in the optimal size of a firm in a given industry, which in turn may create opportunities for taking advantage of synergies by restructuring. Shleifer and Vishny (2003) argue that this can explain a substantial part of the existence of merger waves. On the other hand, many studies offer evidence of value destruction by M\&A activities. Moeller et al. (2005) conclude that shareholders of acquiring companies lost an aggregate $\$ 216$ billion in the period from 1991-2001. As the M\&A activity has the tendency to increase during rising markets and vice versa (Rhodes-Kropf \& Viswanathan, 2004), acquiring firms face the risk of buying companies at high prices and that could also explain why there are some M\&As that add value and others that destroy value. These evidences trigger a number of questions regarding the impact of M\&As for the parties to the restructuring attempt.

This paper focuses on the M\&A among Indian companies and the response of the Indian capital market to such attempts as reflected in the changes in the stock return. An attempt has been made, in this paper, to examine the impact of M\&A announcement on stock returns of the sample acquirer companies. More specifically, it presents the finding of the study that tests the following hypotheses:

Hypothesis-I, that "M\&A announcement generates significantly abnormal returns for acquirer companies after the announcement date". 
Hypothesis II that "Significant abnormal returns do exist for acquirer companies in the pre-announcement period".

The analysis presented in this paper is based on the examination of behavior of share prices of 65 acquirer companies that acquired $15 \%$ or more share during a single event during the period 2000-2010. The data consisted of share prices for a period of 121 days immediately preceding the M\&A announcement and 20 days after M\&A announcement. Cross border M\&As were excluded. Event Study methodology was used for the purpose of data analysis. The single factor market model is estimated using Ordinary least squares (OLS) regression keeping the market movements as the control variable. The estimation window comprise of 100 days (day -120 to day -20). With the help of this procedure, values of $\alpha$ and $\beta$, for our event window ( -20 to +20 days) are obtained. These estimated values of parameters are used to obtain values of expected returns for each day of event window

This paper has been divided into two sections. Section I focuses on the individual as well as aggregate analysis of the impact on stock returns for the acquirer companies. Section II is devoted to analysis of abnormal returns during various time windows in order to explore the possibilities of building profitable trading strategies.

\section{M\&A Announcement and Stock Returns}

This section is concerned with the impact of M\&A announcement on stock returns for the acquiring companies. Generally, one would expect the impact of M\&A announcement on stock returns only after the announcement is made. However, it has been noticed that in many cases there has been a significant change in the share prices during the pre-announcement period. The present study examines the impact on M\&A announcement both during the pre-announcement period and post-announcement period. The study also examines the relationship between the post-announcement period abnormal returns with the pre-announcement period abnormal return.

\subsection{M\&A Announcement and Stock Returns: Post Announcement Period}

The relationship between M\&A announcement and stock returns was examined for the post announcement period ( 0 day to +20 days). The cumulative abnormal returns $(\mathrm{CARj})$ along with the t- statistic for each acquirer company for the post announcement period are given in Table 1.

Table 1. Post-announcement CAR and CAAR: Acquiring companies

\begin{tabular}{|l|r|r|r|}
\hline Company & \multicolumn{1}{c|}{ CARj } & Std. dev. of abnormal return & \multicolumn{1}{c|}{ t-statistic } \\
\hline AC1 & $-0.280706^{*}$ & 0.048380 & -5.802100 \\
\hline AC2 & -0.011570 & 0.018293 & -0.632478 \\
\hline AC3 & $-0.061350^{*}$ & 0.025163 & -2.438150 \\
\hline AC4 & $0.116737^{*}$ & 0.044855 & 2.602548 \\
\hline AC5 & 0.019771 & 0.011611 & 1.702817 \\
\hline AC6 & 0.063702 & 0.031692 & 2.010016 \\
\hline
\end{tabular}




\begin{tabular}{|c|c|c|c|}
\hline AC7 & 0.032479 & 0.045352 & 0.716143 \\
\hline AC8 & -0.017950 & 0.013578 & -1.321950 \\
\hline AC9 & -0.054093 & 0.047081 & -1.148951 \\
\hline $\mathrm{AC10}$ & $-0.135990 *$ & 0.025625 & -5.306950 \\
\hline AC11 & $-0.279531 *$ & 0.091081 & -3.069039 \\
\hline AC12 & 0.027655 & 0.028191 & 0.980983 \\
\hline $\mathrm{AC} 13$ & $0.164136 *$ & 0.020230 & 8.113286 \\
\hline AC14 & $0.024958 *$ & 0.008140 & 3.066199 \\
\hline AC15 & 0.007126 & 0.013496 & 0.527965 \\
\hline AC16 & 0.002821 & 0.027274 & 0.103424 \\
\hline AC17 & $0.074654 *$ & 0.014541 & 5.133991 \\
\hline AC18 & $0.030773 *$ & 0.006123 & 5.025746 \\
\hline AC19 & 0.097012 & 0.048461 & 2.001846 \\
\hline $\mathrm{AC20}$ & 0.011705 & 0.043653 & 0.268150 \\
\hline AC21 & 0.134475 & 0.065056 & 2.067057 \\
\hline $\mathrm{AC22}$ & 0.046261 & 0.032645 & 1.417077 \\
\hline $\mathrm{AC23}$ & $0.036619 *$ & 0.014168 & 2.584546 \\
\hline $\mathrm{AC24}$ & $-0.249208 *$ & 0.044026 & -5.660402 \\
\hline $\mathrm{AC25}$ & $-0.236719 *$ & 0.070746 & -3.346056 \\
\hline AC26 & $-0.206379 *$ & 0.046074 & -4.479333 \\
\hline $\mathrm{AC27}$ & $0.179770 *$ & 0.020266 & 8.870498 \\
\hline $\mathrm{AC28}$ & $-0.165771 *$ & 0.022430 & -7.390498 \\
\hline AC29 & $-0.130643^{*}$ & 0.037984 & -3.439465 \\
\hline AC30 & $-0.202832 *$ & 0.026842 & -7.556553 \\
\hline AC31 & -0.031624 & 0.033761 & -0.936715 \\
\hline AC32 & -0.025907 & 0.026628 & -0.972912 \\
\hline AC33 & $-0.175531 *$ & 0.018790 & -9.341510 \\
\hline AC34 & -0.021002 & 0.051579 & -0.407187 \\
\hline AC35 & -0.025791 & 0.034668 & -0.743953 \\
\hline AC36 & -0.060375 & 0.030607 & -1.972549 \\
\hline AC37 & 0.006205 & 0.055473 & 0.111847 \\
\hline AC38 & -0.043496 & 0.056054 & -0.775960 \\
\hline AC39 & 0.038052 & 0.031483 & 1.208625 \\
\hline AC40 & -0.017285 & 0.016372 & -1.055772 \\
\hline AC41 & $0.077723 *$ & 0.023891 & 3.253171 \\
\hline $\mathrm{AC42}$ & 0.025433 & 0.044389 & 0.572968 \\
\hline $\mathrm{AC43}$ & 0.006163 & 0.006074 & 1.014543 \\
\hline AC44 & 0.125089 & 0.079365 & 1.576133 \\
\hline AC45 & $0.051018 *$ & 0.024213 & 2.107027 \\
\hline AC46 & $0.110026^{*}$ & 0.022026 & 4.995363 \\
\hline AC47 & $-0.274975^{*}$ & 0.061389 & -4.479224 \\
\hline AC48 & $0.418815^{*}$ & 0.055092 & 7.602106 \\
\hline
\end{tabular}




\begin{tabular}{|l|r|r|r|}
\hline AC49 & $0.254613^{*}$ & 0.040605 & 6.270457 \\
\hline AC50 & 0.025333 & 0.025504 & 0.993295 \\
\hline AC51 & $-0.127462^{*}$ & 0.023739 & -5.369327 \\
\hline AC52 & $-0.047215^{*}$ & 0.021777 & -2.168081 \\
\hline AC53 & $0.102110^{*}$ & 0.039295 & 2.598525 \\
\hline AC54 & -0.028678 & 0.021111 & -1.358449 \\
\hline AC55 & -0.033081 & 0.018672 & -1.771699 \\
\hline AC56 & $0.238252^{*}$ & 0.037904 & 6.285671 \\
\hline AC57 & 0.027462 & 0.043421 & 0.632447 \\
\hline AC58 & $0.127989^{*}$ & 0.036975 & 3.461479 \\
\hline AC59 & $-0.058221^{*}$ & 0.014529 & -4.007309 \\
\hline AC60 & $0.065789^{*}$ & 0.029646 & 2.219197 \\
\hline AC61 & $-0.119039^{*}$ & 0.026094 & -4.561996 \\
\hline AC62 & 0.050525 & 0.031131 & 1.622970 \\
\hline AC63 & -0.104561 & 0.067571 & -1.547431 \\
\hline AC64 & 0.084879 & 0.044710 & 1.898465 \\
\hline AC65 & 0.002894 & 0.030196 & 0.095834 \\
\hline
\end{tabular}

*Significant at $5 \%$ level of significance.

Table 1A presents a summary of the results relating to CAR as given in Table 1 along with the values of CAAR for the post announcement period.

Table 1A. Summary of post-announcement CAR and CAAR: Acquiring companies

\begin{tabular}{|l|c|c|c|c|c|}
\hline CARj & Positive & Negative & Total & Positive\% & Negative\% \\
\hline Significant & 16 & 16 & 32 & $25 \%$ & $25 \%$ \\
\hline Insignificant & 20 & 13 & 33 & $31 \%$ & $20 \%$ \\
\hline Total & 36 & 29 & 65 & $55 \%$ & $45 \%$ \\
\hline CAARj & -0.0057 & & & & \\
\hline SCAARj & -1.1923 & & & & \\
\hline
\end{tabular}

Individually, the number of cases where the CAR was significant is 32 out of 65 cases (50\%). This would mean that semi strong efficiency does not hold for acquirer company stocks with regard to M\&A announcement, at individual company level. Out of the cases where CAR was significant, in 16 cases CAR was positive and in 16 cases, it was negative. Thus, the results are mixed and there are equal chances of positive and negative abnormal returns.

On an aggregate basis, CAARj is negative and though statistically not significant. It stood at $-0.57 \%$ for the twenty-one-days period. As there are almost equal number of significantly positive and negative cases, the abnormal returns in a portfolio may be offsetting, thus explaining the aggregate results. Thus, at the portfolio level, abnormal returns are not 
statistically significant due to offsetting of negative abnormal returns by positive abnormal returns, individually. Thus, the hypothesis-I, that "M\&A announcement generates significantly abnormal returns for acquirer companies after the announcement date" is not supported at the aggregate level. Though, it cannot be rejected at company level analysis as in half of cases, significant abnormal returns were observed during the post-announcement period significant abnormal returns exist in half of the cases.

The above findings are consistent with the finding of a number of studies regarding M\&As in India (Sehgal, Banerjee, \& Deisting, 2012; Kumar \& Panneerselvam, 2009; Sehgal, Singh, \& Choudhary, 2005) and M\&As abroad (Mitchell \& Lehn, 1990; Smith \& Kim, 1994; Walker, 2000).

These findings offer valuable inputs for investment analysts. Although, at the portfolio level, abnormal returns are not statistically significant, due to offsetting of negative abnormal returns by positive abnormal returns, in a large proportion of cases, there are significant abnormal returns after M\&A. Thus, the investment analyst cannot ignore the information regarding the M\&A deals. One need to be selective in this regard as there may be other factors such as mode of investment financing used for the transaction which may influence the direction of the abnormal returns on such stocks.

\subsection{M\&A Announcement and Stock Returns: Pre-Announcement Period}

Developed countries have well-developed regulatory framework for corporate governance and investor protection. However, in the emerging market economies like India, such framework is at its infancy and there is lack of strong enforcement mechanism to ensure that insiders are not able to exploit their advantage of having access to information, which other shareholders do not have. Thus, information leakages may take place in such markets. Such leakages may be reflected in the movement of stock prices during the period prior to the announcement of M\&A. Even in mature markets, pre-announcement effect of M\&A has been observed (e.g. Martynova \& Renneboog, 2006; Cheung \& Wong, 2009). Therefore, in the present study, an attempt has also been made to examine the impact of M\&A announcement during the pre-announcement period taking the 20 days window ( -1 day to -20 day). The computed values of the pre-announcement period cumulated abnormal return (CARi) along with the t-statistics for each acquirer company in the sample, for the pre-announcement period is given in Table 2 . 
Table 2. Pre-announcement CAR and CAAR: Acquiring companies

\begin{tabular}{|c|c|c|c|}
\hline Company & CARi & Std. dev. of abnormal return & t-statistic \\
\hline AC1 & 0.060165 & 0.061829 & 0.973091 \\
\hline AC2 & $0.148878^{*}$ & 0.026627 & 5.591248 \\
\hline AC3 & 0.053497 & 0.036424 & 1.468720 \\
\hline AC4 & $0.160043^{*}$ & 0.029915 & 5.349904 \\
\hline AC5 & $-0.042026^{*}$ & 0.016687 & -2.518502 \\
\hline AC6 & 0.040939 & 0.028613 & 1.430759 \\
\hline AC7 & $0.114225^{*}$ & 0.034399 & 3.320626 \\
\hline AC8 & -0.023043 & 0.014535 & -1.585332 \\
\hline AC9 & 0.041270 & 0.035018 & 1.178531 \\
\hline $\mathrm{AC10}$ & $-0.184750 *$ & 0.020845 & -8.862971 \\
\hline AC11 & $0.398202 *$ & 0.043330 & 9.189988 \\
\hline $\mathrm{AC12}$ & $0.160870^{*}$ & 0.057696 & 2.788218 \\
\hline $\mathrm{AC13}$ & $0.132009^{*}$ & 0.019806 & 6.664978 \\
\hline $\mathrm{AC14}$ & $0.092864 *$ & 0.030269 & 3.068002 \\
\hline AC15 & $0.074595^{*}$ & 0.013084 & 5.701139 \\
\hline AC16 & $0.109351^{*}$ & 0.044921 & 2.434284 \\
\hline AC17 & $0.038042 *$ & 0.009856 & 3.859907 \\
\hline AC18 & $0.058001^{*}$ & 0.010160 & 5.708739 \\
\hline AC19 & 0.204247 & 0.223028 & 0.915791 \\
\hline AC20 & $-0.298705^{*}$ & 0.033421 & -8.937669 \\
\hline AC21 & $0.122671^{*}$ & 0.017337 & 7.075595 \\
\hline $\mathrm{AC22}$ & $0.075540^{*}$ & 0.020343 & 3.713368 \\
\hline $\mathrm{AC23}$ & $-0.223231 *$ & 0.020350 & -10.969696 \\
\hline AC24 & $0.072768^{*}$ & 0.019952 & 3.647192 \\
\hline $\mathrm{AC25}$ & $-0.207773 *$ & 0.033947 & -6.120466 \\
\hline AC26 & 0.034272 & 0.044427 & 0.771429 \\
\hline AC27 & $0.061314 *$ & 0.020709 & 2.960658 \\
\hline $\mathrm{AC28}$ & -0.021108 & 0.020115 & -1.049368 \\
\hline AC29 & $0.110927 *$ & 0.039576 & 2.802907 \\
\hline AC30 & -0.022878 & 0.044191 & -0.517703 \\
\hline AC31 & $0.257139 *$ & 0.030589 & 8.406174 \\
\hline AC32 & $-0.127193 *$ & 0.026728 & -4.758775 \\
\hline AC33 & $0.123931^{*}$ & 0.017986 & 6.890291 \\
\hline AC34 & $0.148082 *$ & 0.018476 & 8.015024 \\
\hline AC35 & $-0.149913 *$ & 0.042275 & -3.546115 \\
\hline AC36 & 0.056993 & 0.033022 & 1.725924 \\
\hline AC37 & $0.672897 *$ & 0.075099 & 8.960120 \\
\hline AC38 & $0.441408^{*}$ & 0.070721 & 6.241510 \\
\hline AC39 & $0.336689 *$ & 0.021381 & 15.746867 \\
\hline
\end{tabular}




\begin{tabular}{|c|c|c|c|}
\hline Company & CARi & Std. dev. of abnormal return & t-statistic \\
\hline AC40 & $-0.064771^{*}$ & 0.013575 & -4.771532 \\
\hline AC41 & $0.273977^{*}$ & 0.048013 & 5.706288 \\
\hline AC42 & $-0.220185^{*}$ & 0.019280 & -11.420181 \\
\hline AC43 & 0.020270 & 0.010689 & 1.896354 \\
\hline AC44 & 0.047991 & 0.028329 & 1.694057 \\
\hline AC45 & $-0.058717^{*}$ & 0.023181 & -2.533023 \\
\hline AC46 & $-0.123692^{*}$ & 0.014972 & -8.261676 \\
\hline AC47 & $-0.191299^{*}$ & 0.043319 & -4.416043 \\
\hline AC48 & 0.057834 & 0.035202 & 1.642899 \\
\hline AC49 & $-0.252745^{*}$ & 0.027139 & -9.312891 \\
\hline AC50 & -0.000154 & 0.027478 & -0.005587 \\
\hline AC51 & $-0.064409^{*}$ & 0.008913 & -7.226273 \\
\hline AC52 & $0.192301^{*}$ & 0.022572 & 8.519368 \\
\hline AC53 & $-0.239245^{*}$ & 0.025543 & -9.366248 \\
\hline AC54 & $-0.100108^{*}$ & 0.029560 & -3.386662 \\
\hline AC55 & $-0.030048^{*}$ & 0.023721 & -1.266706 \\
\hline AC56 & 0.022959 & 0.024473 & 0.938158 \\
\hline AC57 & $0.151691^{*}$ & 0.034833 & 4.354760 \\
\hline AC58 & -0.064004 & 0.062921 & -1.017207 \\
\hline AC59 & $0.214082^{*}$ & 0.025759 & 8.310875 \\
\hline AC60 & $-0.076252^{*}$ & 0.014272 & -5.342766 \\
\hline AC61 & $-0.119039^{*}$ & 0.026094 & -4.561996 \\
\hline AC62 & 0.050525 & 0.031131 & 1.622970 \\
\hline AC63 & -0.104561 & 0.067571 & 0.095834 \\
\hline AC64 & 0.084879 & 0.044710 & \\
\hline AC65 & 0.002894 & 0.030196 & \\
\hline
\end{tabular}

Note. *Significant at $5 \%$ level of significance.

Table $2 \mathrm{~A}$ presents a summary of the results relating to CAR, along with the values of CAAR for the pre announcement period.

Table 2A. Summary of Pre-announcement CAR and CAAR: Acquiring companies

\begin{tabular}{|l|c|c|c|c|c|}
\hline CARi & Positive & Negative & Total & Positive\% & Negative\% \\
\hline Significant & 27 & 18 & 45 & $42 \%$ & $28 \%$ \\
\hline Insignificant & 14 & 6 & 20 & $22 \%$ & $9 \%$ \\
\hline Total & 41 & 24 & 65 & $63 \%$ & $37 \%$ \\
\hline CAARi & 0.04887 & & & & \\
\hline SCAARi & 9.15695 & & & & \\
\hline
\end{tabular}


CAR analysis for individual companies in the sample is presented in Table 2. Individually, more than two-third (70\%) of the sample companies witnessed statistically significant CAR values during the pre announcement period. Out of 65 acquirer companies in the sample, $42 \%$ have positive and significant pre-announcement period CAR values, as compared to $25 \%$ during the post-announcement period. However, only $28 \%$ of companies had significant negative CAR during the pre-announcement period. Individually, it is more likely that CAR is significantly positive than negative during pre-announcement period. On aggregate level, for all acquirer companies as a whole, the CAAR is positive (4.89\%) and statistically significant at $5 \%$ level of significance, during the pre-announcement period.

Thus, the hypothesis II that "Significant abnormal returns do exist for acquirer companies in the pre-announcement period" is supported, both for the individual level analysis as well as aggregate level analysis. However, in the individual level analysis, the results are mixed with regard to direction of abnormal returns and positive abnormal returns occur more often than negative abnormal returns, during the pre-announcement period. On aggregate basis, there are positive and significant abnormal returns. The results in the aggregate level analysis are consistent with that in the individual level analysis as the positive abnormal returns occur more often that the negative abnormal returns.

The existence of statistically significant CAR in many cases during the pre-announcement period points toward possibility of leakages of M\&A information which may be exploited by the market traders on pre event basis. As CAR is statistically significant in majority (70\%) of the cases and not in exceptional cases, and it should be matter of concern for the market regulator (viz. SEBI). This reflects the inefficiency of the market and needs to be corrected for healthy development of the market. SEBI should improve it surveillance mechanism regarding price manipulation and insider trading, particularly around the M\&A announcement

The results of the study provide clinching evidence in support of the contention that market reacts significantly to any leakage of information regarding possible M\&A deal before the date of announcement, as it does exhibit significant abnormal returns in the pre-announcement period. These abnormal returns could arise either due to the rumours or possible leakage of information regarding the impending M\&A announcement resulting in reactions from some of the players even before the public announcement of M\&A deal. For the regulator, it may be difficult to regulate and completely eliminate the possibility of rumours. But if the pre-announcement period CAR arises due to leakage of information, it reflects weak regulation and presence of insider trading. In the following analysis, an attempt has been made to examine this issue and determine whether the significant pre-announcement CAR could be attributed to rumours or to leakage of information.

\section{Abnormal Returns in Different Time Window}

This section is devoted to analysis of abnormal returns during various time windows.

\subsection{Average Abnormal Return During Different Time Windows:}

An attempt was also made to analyze the behavior of average abnormal returns for the sample 
acquirer companies during different time windows. Such an analysis may be useful in understanding the pattern of price reaction and also in formulating profit making trading strategies.

\subsubsection{AAR and CAAR During the Post-Announcement Period}

In order to get some clues regarding the potential opportunities for generating abnormal returns, the behavior of average abnormal returns (AARs) and cumulative average abnormal returns (CAARs) were examined for 20 windows, each window being bigger than the previous one by a day. Table 3 presents AARs, CAARs and the t values for various time windows during the post announcement period of 21 days (day 0 to day 20). In addition, an attempt was also made to divide the post-announcement window $(0,+20)$ into two windows.

Table 3. Average abnormal returns during post-announcement period: Acquirer companies

\begin{tabular}{|c|c|c|c|c|}
\hline Window Day & \#AAR & CAAR & SE_CAAR & t-statistic \\
\hline$(0,0)$ & 0.011288 & - & - & - \\
\hline$(0,1)$ & -0.002949 & 0.00834 & - & - \\
\hline$(0,2)$ & -0.001289 & 0.00705 & - & - \\
\hline$(0,3)$ & -0.001239 & 0.00581 & - & - \\
\hline$(0,4)$ & 0.000736 & 0.00655 & - & - \\
\hline$(0,5)$ & -0.007144 & -0.00060 & 0.00533 & -0.11186 \\
\hline$(0,6)$ & 0.000759 & 0.00016 & 0.00527 & 0.03090 \\
\hline$(0,7)$ & -0.003193 & -0.00303 & 0.00507 & -0.59833 \\
\hline$(0,8)$ & 0.005999 & 0.00297 & 0.00497 & 0.59741 \\
\hline$(0,9)$ & 0.002492 & 0.00546 & 0.00498 & 1.09710 \\
\hline$(0,10)$ & 0.004623 & $0.01008^{*}$ & 0.00503 & 2.00567 \\
\hline$(0,11)$ & -0.000195 & $0.00989^{*}$ & 0.00500 & 1.97900 \\
\hline$(0,12)$ & -0.000055 & $0.00983 *$ & 0.00498 & 1.97358 \\
\hline$(0,13)$ & -0.000620 & 0.00921 & 0.00500 & 1.84220 \\
\hline$(0,14)$ & -0.005381 & 0.00383 & 0.00492 & 0.77956 \\
\hline$(0,15)$ & -0.001564 & 0.00227 & 0.00487 & 0.46536 \\
\hline$(0,16)$ & -0.001588 & 0.00068 & 0.00479 & 0.14210 \\
\hline$(0,17)$ & -0.004615 & -0.00394 & 0.00472 & -0.83321 \\
\hline$(0,18)$ & 0.000876 & -0.00306 & 0.00472 & -0.64875 \\
\hline$(0,19)$ & 0.003276 & 0.00022 & 0.00472 & 0.04581 \\
\hline$(0,20)$ & -0.005916 & -0.00570 & 0.00478 & -1.19234 \\
\hline$(11,20)$ & - & $-0.01578^{*}$ & 0.00450 & -3.50658 \\
\hline
\end{tabular}

Note. The SE_CAAR and t values have not been computed for the first five windows due very small number of observations (days) in these windows.

*Values are significant at 5\% level of significance.

\#AAR Relates to the last day in the window. 
An analysis direction of the AARs during the post announcement period for the acquiring companies suggests no specific pattern. However, a noteworthy feature of AARs in this window is that AAR for the day 0 is positive (1.13\% for a day) and exceptionally higher than those for the other days in the window.

It may be re-called that CAAR for the post-announcement window (day 0 to +20 days) was negative (-0.0057) and insignificant. It may be observed from Table 3 that the CAAR remained positive till the day 5 (inspite of three consecutive days with negative AAR) due to the high value of AAR on day 0. CAAR for acquiring companies was statistically insignificant for each of the windows during the post-announcement period, except for windows 0,$10 ; 0,11$ and 0,12 . This explains the insignificant CAAR for the post-announcement period. Moreover, the cumulative average abnormal returns tend to die out after first 13 days. Thus, it may be concluded that opportunities for abnormal returns are rare on the shares of acquirer companies during the post-announcement period. Moreover, significant cumulative average abnormal returns are not necessarily clustering in the narrow windows close to the date of announcement and may occur at later dates but the interest of the investor in these shares starts fading away after 10 days of M\&A announcement. It may also be noted that the CAAR for the window (11, 20 day) was negative and statistically significant. This implies that after the 10 days, the CAAR is negative and significant and positive returns are primarily in the first 10 days of announcement.

\subsubsection{CAAR During the Pre-Announcement Period}

An analysis of the behavior of AAR and CAAR during the pre-announcement period was examined during 19 windows, each window being bigger than the previous by a day. Table 4 presents cumulative daily average abnormal returns and the $t$ values for various time windows in the pre announcement period of 20 days (day -1 to day -20). In addition, an attempt was also made to divide the pre-announcement window $(-1,-20)$ into two windows, $(-1,-10)$ and $(-11,-20)$.

Table 4.Average abnormal returns during pre-announcement period: Acquirer companies

\begin{tabular}{|c|c|c|c|c|}
\hline Window Day & \#AAR & CAAR & SE_CAAR & t-statistic \\
\hline$(-1,-1)$ & 0.007231 & - & - & - \\
\hline$(-1,-2)$ & 0.000169 & 0.007400 & - & - \\
\hline$(-1,-3)$ & 0.003545 & 0.010946 & - & - \\
\hline$(-1,-4)$ & 0.006281 & 0.017226 & - & - \\
\hline$(-1,-5)$ & -0.005143 & 0.012083 & - & - \\
\hline$(-1,-6)$ & -0.001061 & $0.011023^{*}$ & 0.004139 & 2.663223 \\
\hline$(-1,-7)$ & 0.003425 & $0.014447^{*}$ & 0.004007 & 3.605533 \\
\hline$(-1,-8)$ & 0.003828 & $0.018276^{*}$ & 0.003989 & 4.581353 \\
\hline$(-1,-9)$ & 0.003201 & $0.021477^{*}$ & 0.004022 & 5.340095 \\
\hline$(-1,-10)$ & -0.000996 & $0.020480^{*}$ & 0.003976 & 5.151083 \\
\hline$(-1,-11)$ & 0.006691 & $0.027172 *$ & 0.003990 & 6.810586 \\
\hline
\end{tabular}




\begin{tabular}{|c|c|c|c|c|}
\hline Window Day & \#AAR & CAAR & SE_CAAR & t-statistic \\
\hline$(-1,-12)$ & -0.002464 & $0.024708^{*}$ & 0.004027 & 6.134876 \\
\hline$(-1,-13)$ & -0.003029 & $0.021679^{*}$ & 0.004035 & 5.373042 \\
\hline$(-1,-14)$ & 0.001928 & $0.023607^{*}$ & 0.004034 & 5.852643 \\
\hline$(-1,-15)$ & 0.001608 & $0.025215^{*}$ & 0.004141 & 6.089668 \\
\hline$(-1,-16)$ & -0.000372 & $0.024843^{*}$ & 0.004122 & 6.026581 \\
\hline$(-1,-17)$ & 0.007090 & $0.031933^{*}$ & 0.004095 & 7.797441 \\
\hline$(-1,-18)$ & -0.003167 & $0.028766^{*}$ & 0.004808 & 5.983132 \\
\hline$(-1,-19)$ & 0.010998 & $0.039764^{*}$ & 0.004788 & 8.305194 \\
\hline$(-1,-20)$ & 0.009104 & $0.048868^{*}$ & 0.005337 & 9.156947 \\
\hline$(-11,-20)$ & - & $0.028387^{*}$ & 0.006503 & 4.365557 \\
\hline
\end{tabular}

Note. The SE_CAAR and t values have not been computed for the first five windows due very small number of observations (days) in these windows.

*Values are significant at $5 \%$ level of significance.

\#AAR Relates to the last day in the window.

As may be observed from the Table 4 , AAR is positive from -4 day to -1 . Before that no specific pattern could be observed.

As mentioned in Table 2A, CAAR for the pre-announcement window (day -1 to -20 days) was positive (0.048868) and significant. CAAR for acquiring companies was positive and statistically significant for each of the windows during the pre-announcement period without any exception. This explains the positive and significant CAAR for the pre-announcement period. Moreover, the cumulative abnormal returns show a tendency to increase as we expand the window, indicating that average abnormal returns are high as early as 20 days before the M\&A announcement. It is interesting to note that CAAR is 0.028387 and statistically significant during the window $-11,-20$ day, as compared to CAAR is 0.020480 for the window $-1,-10$. Thus, it may be concluded that there are opportunities for generating abnormal returns in each of the windows selected during the pre-announcement. Moreover, it is also observed that longer is the window, greater is the value of CAAR during the 20 days pre-announcement period and positive AARs are higher in the earlier half of the window as compared to the one close to the date of the announcement.

\subsubsection{CAAR and AAR During the 41 Days Around the Date of Announcement}

An attempt was also made to examine the behavior of cumulative abnormal returns during the time windows covering both the pre-announcement and post-announcement period. For this purpose, 20 windows were formed by adding one day before the announcement and one day after the announcement to the previous window. The CAAR and the $t$ value for each of the windows are given in Table 5 
Table 5. Average abnormal returns around the announcement date (Acquirer companies)

\begin{tabular}{|c|c|c|c|}
\hline Window Day & CAAR & SE_CAAR & t-statistic \\
\hline$(-1,+1)$ & 0.015570 & - & - \\
\hline$(-2,+2)$ & $0.014450^{*}$ & 0.005178 & 2.790625 \\
\hline$(-3,+3)$ & $0.016757^{*}$ & 0.005167 & 3.243035 \\
\hline$(-4,+4)$ & $0.023774^{*}$ & 0.005137 & 4.628284 \\
\hline$(-5,+5)$ & $0.011487^{*}$ & 0.004915 & 2.337053 \\
\hline$(-6,+6)$ & $0.011185^{*}$ & 0.004786 & 2.336918 \\
\hline$(-7,+7)$ & $0.011416^{*}$ & 0.004595 & 2.484560 \\
\hline$(-8,+8)$ & $0.021244^{*}$ & 0.004524 & 4.695490 \\
\hline$(-9,+9)$ & $0.026937^{*}$ & 0.004534 & 5.940559 \\
\hline$(-10,+10)$ & $0.030563^{*}$ & 0.004537 & 6.736006 \\
\hline$(-11,+11)$ & $0.037060^{*}$ & 0.004525 & 8.189795 \\
\hline$(-12,+12)$ & $0.034541^{*}$ & 0.004533 & 7.620516 \\
\hline$(-13,+13)$ & $0.030892^{*}$ & 0.004534 & 6.813982 \\
\hline$(-14,+14)$ & $0.027440^{*}$ & 0.004495 & 6.104331 \\
\hline$(-15,+15)$ & $0.027484^{*}$ & 0.004514 & 6.088282 \\
\hline$(-16,+16)$ & $0.025523^{*}$ & 0.004456 & 5.728440 \\
\hline$(-17,+17)$ & $0.027998^{*}$ & 0.004412 & 6.345579 \\
\hline$(-18,+18)$ & $0.025706^{*}$ & 0.004750 & 5.412404 \\
\hline$(-19,+19)$ & $0.039980^{*}$ & 0.004748 & 8.420931 \\
\hline$(-20,+20)$ & $0.043168^{*}$ & 0.004788 & 9.015067 \\
\hline
\end{tabular}

Note. The SE_CAAR and $\mathrm{t}$ values have not been computed for the first window due very small number of observations (days) in this window.

*Values are significant at $5 \%$ level of significance.

As may be observed from the above Table 5, CAAR for acquiring companies was positive and statistically significant for each of the windows during the 41 day period around the date of announcement, without any exception. This is perhaps because of high positive abnormal returns during the pre-announcement period and insignificant average abnormal returns during the post-announcement period. However, the cumulative abnormal returns do not exhibit any fixed pattern of behavior in either direction. This is perhaps due to the negative though insignificant average abnormal returns during the post-announcement period. Thus, it may be concluded that there are opportunities for generating abnormal returns in each of the windows selected during the 41-day period around the date of announcement date.

Figure 1 presents the behavior of AAR during the entire 41 days period around the date of announcement. 


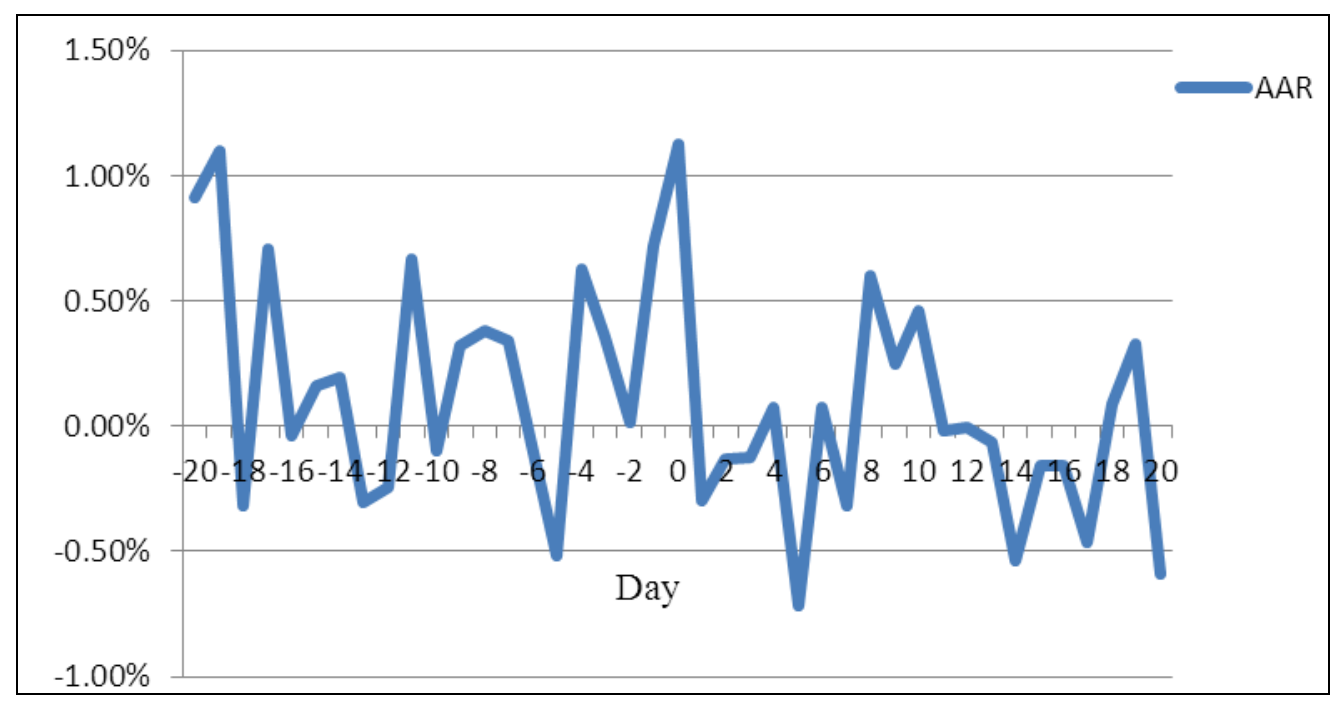

Figure 1. AARs during the 41 day period (Acquirer companies)

The Figure points towards an important window that offers opportunities for developing trading strategies is $-4,0$. For this five-day window, the CAAR is $2.85 \%$, which is very high for such a short window. Another window of opportunity for developing profitable trading strategy is $-19,-20$ which has a CAAR of $2.01 \%$ for a small window of 2 days. The investment manager can go long during these windows and earn extra-normal returns. For the remaining period, no specific pattern was observed.

\section{Summary and Conclusion}

The above analysis offers very useful conclusions about the market reaction to M\&A announcement for acquirer companies in India. On ex-post basis, individual analysis suggests that there is significant impact of M\&A announcement on stock returns for almost half of the sample acquirer companies. In other words, the Indian stock market is not efficient in the semi-strong form with respect to M\&A announcement information for acquirer companies. Thus, the investment analyst cannot ignore the information regarding the M\&A deals. The results relating to the direction of price reaction are, however, mixed as positive abnormal returns occur as often as negative abnormal returns on post-event basis. On aggregate basis, CAARj is statistically not significant. It stood at $-0.57 \%(\mathrm{t}$-statistic $=-1.19234)$ for the twenty-one-days period.

During the pre-announcement period, more than two-third of the sample companies witnessed statistically significant CAR values. Individually, positive CAR occurs more often than the negative CAR during this period. At aggregate level, the CAAR is positive and statistically significant with a value of $4.89 \%$ (t-statistic=9.156947). Thus, the study offers a clinching evidence for existence of significant abnormal returns even before the M\&A announcement. The existence of statistically significant CAR in many cases during the pre-announcement period points toward possibility of leakages of M\&A information which may be exploited by the market traders on pre event basis. 


\section{Mll Macrothink}

World Journal of Business and Management

ISSN 2377-4622

2017, Vol. 3, No. 1

These findings are consistent with the finding of a number of studies regarding M\&As in India (Sehgal, Banerjee, \& Deisting, 2012; Kumar \& Panneerselvam 2009; Sehgal, Singh, \& Choudhary, 2005) and M\&As abroad (Mitchell \& Lehn 1990; Smith \& Kim 1994; Walker 2000). It was further observed that the direction of the pre-announcement CAR for the acquirer companies provides useful information regarding the direction of CAR in the post announcement period. An analysis of post-event abnormal returns during various time windows also provides very useful clues for investment analysts. Observing the pattern of post-event CAARs for different short-term event windows, significantly positive CAAR of almost $1.01 \%$ (t-statistics=2.00567) is reported over the first 11 days (including the event day). This is in contrast with CAAR during later half of the post event period (-11,-20 day) which was $-1.58 \%$ (t-statistic $=-3.50658$ ). Thus, investors seem to be optimistic in the first phase of post event period, which is followed by correction in the second phase resulting in negative returns. From the perspective of investment analyst, the best portfolio formation window seems to be $(-4,0$ day), promising a cumulative return of about $2.85 \%$ for the 5 day period. Thus, the investment analyst can build profitable trading strategies by taking long positions in acquiring company's stocks 4 days prior to the M\&A announcement date and exit at the end of the event day.

\section{References}

Cheung, K. Y., \& Wong, A. (2009). The Effects of Merger and Acquisition Announcements on the Security Prices of Bidding Firms and Target Firms in Asia. International Journal of Economics and Finance, 1(2), 274-283. http://dx.doi.org/10.5539/ijef.v1n2p274

Kumar M., Kumar S., \& Deisting F. (2013) Wealth effects of bank mergers in India: A study of impact on share prices, volatility and liquidity. Banks and Bank Systems, 8(1).

Kumar, B. R., Panneerselvam, S., \& Siddaganga, S. (2009) Mergers, Acquisitions and Wealth Creation: A Comparative Study in the Indian Context. IIMB Management Review, 222-244.

Martynova, M., \& Renneboog, L. (2006). The Performance of the European Market for Corporate Control: Evidence from the 5th Takeover Wave (ECGI - Finance Working Paper No. 135/2006).

Martynova, M., \& Renneboog, L. (2009). What determines the financing decision in corporate takeovers: Cost of capital, agency problems, or the means of payment? Journal of Corporate Finance, 15(3), 290-315. https://doi.org/10.1016/j.jcorpfin.2008.12.004

Mitchell, M. L., \& Lehn, K. (1990). Do Bad Bidders Become Good Targets? Journal of Political Economy, 98, 372-98. https://doi.org/10.1086/261682

Moeller, S. B., Schlingemann, F. P., \& Stulz, R. M. (2005). Wealth Destruction on a Massive Scale? A Study of Acquiring-Firm Returns in the Recent Merger Wave. The Journal of Finance, LX(2), 757-782. http://dx.doi.org/10.1111/j.1540-6261.2005.00745.x

Rhodes-Kropf, M., \& Viswanathan, S. (2004). Market Valuation and Merger Waves. The Journal of Finance, LIX(6), 2685-271. https://doi.org/10.1111/j.1540-6261.2004.00713.x 


\section{Macrothink}

World Journal of Business and Management

ISSN 2377-4622

2017, Vol. 3, No. 1

Sehgal, S., Banerjee, S., \& Deisting, F. (2012) The impact of M\&A announcement and financing strategy on stock returns: Evidence from BRICKS markets. International Journal of Economics and Finance, 4(11). https://doi.org/10.5539/ijef.v4n11p76

Shleifer, A., \& Vishny, R. W. (2003). Stock Market Driven Acquisitions. Journal of Financial Economics, 70, 295-311 http://dx.doi.org/10.1016/S0304-405X(03)00211-3

Smith, A., \& Kim, J. (1994). The combined effects of free cash flow and financial slack on bidder and target stock returns. Journal of Business, 67, 281-310. http://dx.doi.org/10.1086/296633

Sudarsanam, S. (2003). Creating Value from Mergers and Acquisitions - The Challenges (1st ed.). Prentice Hall.

Walker, M. (2000). Corporate takeovers, strategic objectives and acquiring firm shareholder wealth. Financial Management, 53-66. https://doi.org/10.2307/3666361

\section{Copyright Disclaimer}

Copyright for this article is retained by the author(s), with first publication rights granted to the journal.

This is an open-access article distributed under the terms and conditions of the Creative Commons Attribution license (http://creativecommons.org/licenses/by/3.0/). 